\title{
CELLULOSE NANOFIBERS IN WOOD: TINY STRUCTURAL ELEMENTS WITH A HUGE EFFECT ZELLULOSE-NANOFASERN IN HOLZ: KLEINE STRUKTURELEMENTE MIT GROSSER WIRKUNG
}

For centuries, wood has evoked the widest variety of associations. Some look at it as a material for buildings and furniture, for artworks and items of everyday use, while others see it as the flexible tissue of a gigantic living plant.

Another view opens up when you start exploring the inner workings of wood. With the aid of various microscopic and material-characterization techniques, the finest structures can be rendered visible on both a micrometric and nanometric scale. Today we know that these minute details have massive effects on the mechanical properties of wood and probably also offer an opportunity for the tree to tune these properties to fit its needs.

Wood consists of long tubular cells oriented along the stem or branch. These cells conduct water and lend the tree mechanical stability. The cell wall itself consists of crystalline cellulose nanofibrils embedded in an amorphous matrix, which they mechanically reinforce. They are wrapped around the cell in multiple layers and exhibit different orientations in the different layers (Fig. 1). Of
Seit Hunderten von Jahren weckt Holz die unterschiedlichsten Assoziationen. Während es die einen als Werkstoff für Bauten, Möbel, Kunstwerke und Dinge des täglichen Bedarfs sehen, erblicken andere darin das flexible Gewebe einer lebenden Pflanze von ungeheurer Größe.

Ein noch anderer Blick eröffnet sich, wenn man das Innere von Holz erforscht. Mit unterschiedlichen Mikroskopie- und Materialcharakterisierungstechniken können feinste Strukturen auf Mikrometer- und Nanometerebene sichtbar gemacht werden. Von diesen kleinsten Details weiß man heute, dass sie massive Auswirkungen auf die mechanischen Eigenschaften von Holz haben und wohl eine Möglichkeit für den Baum darstellen, diese nach Bedarf maßzuschneidern.

Holz besteht aus langgestreckten, röhrenförmigen Zellen, die entlang des Stammes oder des Astes ausgerichtet sind. Sie dienen der Wasserleitung und der mechanischen Stabilisierung des Baumes. Die Zellwand selbst besteht aus kristallinen Zellulose-Nanofibrillen, die in einer amorphen Matrix eingebettet sind 

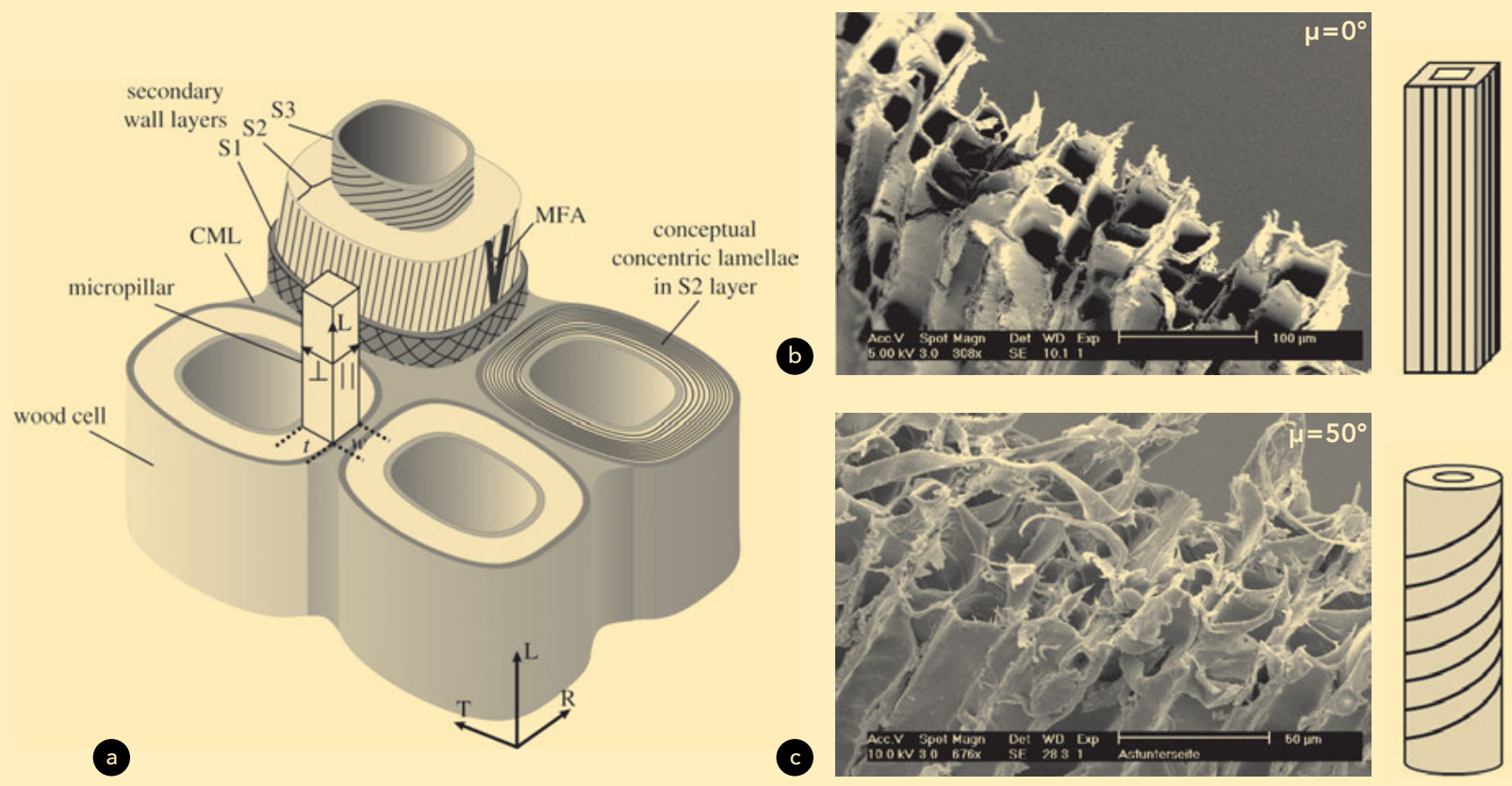

mechanical significance in this context is the secondary wall 2 (S2), the thickest layer. The cellulose nanofabrils there are oriented parallel to each other and tilted slightly with respect to the longitudinal axis of the cell. This tilt angle, known scientifically as the microfibril angle (MFA), can vary greatly within a tree and plays a crucial part in mechanical behavior. If the MFA is large, the cellulose nanofibers describe a rather flat spiral, which is what makes the wood soft and elastic. If the MFA is small, in other words, if the fibers are largely oriented along the cell axis, the resulting material is stiff and strong. ${ }^{1}$

Although the individual cellulose nanofibers may seem small and nondescript, their orientation alone provides the tree with a highly effective way to engage in mechanical adaptation. It is well-known that young trees and branches possess flexible wood with a large MFA, whereas a small MFA is found in the strong and stiff stem wood of older trees. ${ }^{2}$ This is easy to verify since und diese mechanisch verstärken. Sie sind in mehreren Lagen um die Zelle herumgewickelt und weisen in den unterschiedlichen Lagen unterschiedliche Orientierung auf (Abb. 1). Mechanisch bedeutsam ist dabei die sogenannte Sekundärwand 2 (S2), die dickste Schicht. Dort sind die Zellulose-Nanofibrillen parallel zueinander ausgerichtet und leicht gegen die Längsachse der Zelle verkippt. Dieser Kippwinkel, in der Fachsprache Mikrofibrillenwinkel (MFA) genannt, kann innerhalb eines Baumes sehr unterschiedlich ausfallen und spielt eine entscheidende Rolle für das mechanische Verhalten. Ist der MFA groß, beschreiben die ZelluloseNanofasern also eine eher flache Spirale, so ist das Holz weich und dehnbar. Ist der MFA klein, die Fasern also im Wesentlichen längs der Zellachse ausgerichtet, so ergibt sich ein steifes und festes Material.?

So klein und unscheinbar die einzelnen Zellulose-Nanofasern erscheinen, ergibt sich doch allein aufgrund ihrer Orientierung für die Pflanze ein sehr wirkungsvolles Mittel der
\Fig. 1 | Abb. 1:

Nanostructure of the wood cell wall:

a) Structure of the layers of wood cells. The tilt angle (i.e. microfibril angle, MFA) of the cellulose nanofibers is drawn in, with permission from [ $\left.{ }^{8}\right]$.

b) Fracture behavior of wood cells with small MFA: minimal deformation and brittle fracture.

c) Compression wood with a large MFA is observed to have substantially greater elasticity and major plastic deformation; with permission from [ $\left.{ }^{\circ}\right]$. 
tree stems grow solely by depositing cells in a thin layer between wood and bark, the cambium, and never rid themselves of these cells from their youth. In this way, each stem writes its own history, including its mechanical history, which includes the bending loads it has been subjected to.

An effective way for a tree to withstand bending loads is for it to form 'reaction wood', a tissue with special mechanical functions. This is found in branches and stems of trees that grow on steep slopes and need to correct themselves into an upright position. In softwoods, reaction wood is called 'compression wood' (CW) and is found on the lower side (compression side) of the trunk or branch. It consists of round wood cells with especially thick walls. These cells are extremely stable under compressive loads and, not least of all, have a high lignin content. Lignin acts as an adhesive and stiffens the matrix of the wood cell wall. In compression wood cells, large amounts of lignin are placed between the cellulose nanofibers after cellulose synthesis. This massive lignification becomes particularly effective in conjunction with a large MFA, i.e. when the cellulose nanofibers are arranged in a flat spiral. The deposition of lignin expands the spiral in the longitudinal direction (Fig. 2). This small effect - occurring collectively - results in a considerable push-up effect that can push the entire stem upward. In this way, trees can not only adapt continuously but also execute movements, for example, orienting twigs towards light.

Several factors can be cited as triggers for the formation of reaction wood, for instance, light and gravity, as well as induced mechanical mechanischen Anpassung. Es ist bekannt, dass junge Bäume und Äste biegsames Holz mit einem großen MFA besitzen, während im festen und steifen Stammholz von älteren Bäumen kleinere MFA gefunden werden. ${ }^{2}$ Dies ist leicht nachzuprüfen, da Baumstämme nur durch Anlagerung von Zellen in einer dünnen Schicht zwischen Holz und Rinde, dem Kambium, wachsen und die Zellen aus ihrer Jugend nie abbauen. So schreibt also jeder Stamm seine eigene, auch mechanische Geschichte, wie zum Beispiel Biegebelastungen.

Eine effektive Möglichkeit, um Biegebelastungen standzuhalten, ist die Ausbildung von sogenanntem Reaktionsholz, einem Gewebe von besonderer mechanischer Funktionalität. Man findet es in Ästen oder in Stämmen von Bäumen, die auf steilen Hängen wachsen und die sich aufrichten müssen. Bei Nadelbäumen findet man Druckholz (compression wood, CW) an der Unterseite (der Druckseite) des Stammes oder Astes. Es besteht aus besonders dickwandigen, runden Holzzellen. Diese sind äußerst stabil unter Druckbelastung und enthalten nicht zuletzt auch eine Menge Lignin. Lignin fungiert als Kleber und versteift die Matrix der Holzzellwand. In Druckholzzellen wird es nach der Zellulosesynthese in großen Mengen zwischen die Zellulose-Nanofasern eingebaut. Besonders wirksam wird die massive Lignifizierung im Zusammenhang mit einem großen MFA, also der Anordnung von Zellulose-Nanofasern in einer flachen Spirale. Die Einlagerung von Lignin führt dabei zu einer Expansion der Spirale in Längsrichtung (Abb. 2). Dieser kleine Effekt ergibt - kollektiv ausgeführt - einen beachtlichen „Pushup"-Effekt, der ganze Stämme in die Höhe drücken kann. Auf diese Weise ist es Bäumen möglich, sich nicht nur kontinuierlich anzupassen, sondern 

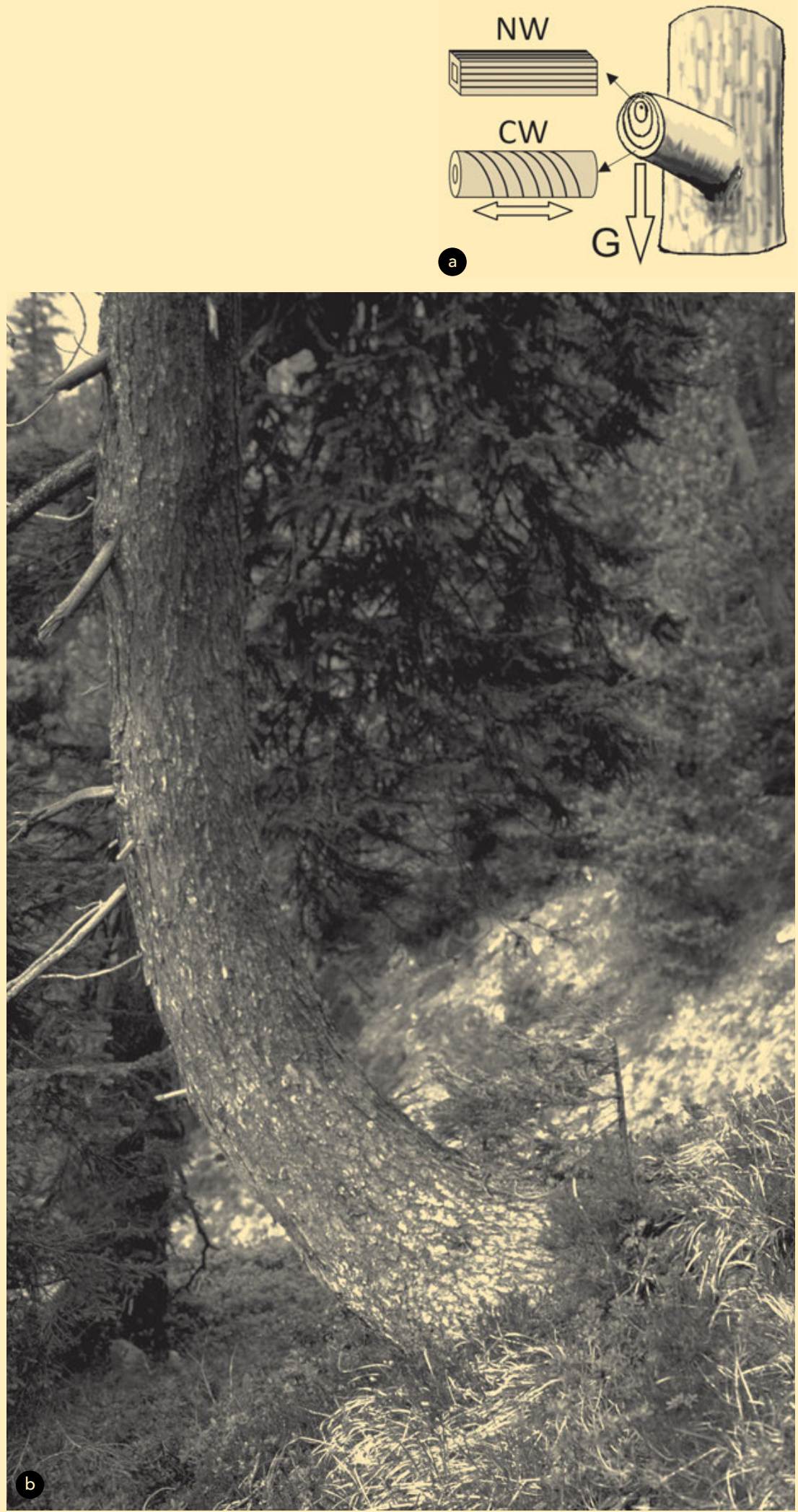

44 Fig. 2 | Abb. 2:

Push-up effect due to lignification of the compression wood (CW) cells. a) Difference in the anatomy of the wood within the branch: on the lower side of the branch, $\mathrm{CW}$ with wide MFA; on the upper side, normal wood (NW). b) Typical sweep of the bole growth in coniferous tree caused by pressure from snow loads. Nonetheless, the stem can put itself upright.

Photo by Ulrich Wasem (Swiss Federal Institute for Forest, Snow and Landscape Research (WSL), Switzerland), with kind permission. 
stimuli. Thus, an experiment conducted in a microgravity environment showed that induced mechanical stress led to the formation of reaction wood in young Douglas fir seedlings. ${ }^{3}$ This means that plants apparently have a sensorium for mechanical stress. In experiments involving fir branches, we were able to demonstrate that induced upward bending of the branch caused the formation of compression wood with a large MFA on the upper side of the branch although this formation is otherwise always observed on the lower side. The branch counters the bending with resistance, namely not just when subjected to downward bend-ing but also to upward bending towards light. The exact mechanisms for this are still unclear, but could nevertheless provide crucial inspirations for new, bio-inspired fiber composites with an optimized nanostructure.

Directly replicating the wood cell is a big challenge, however, and has never been done successfully due to the cell's complexity and the small size of its components. Thus far, only a few aspects of the wood cell wall have been duplicated in new composites. For instance, Gordon and Jeronomidis crafted a simplified macroscopic model in which carbon fibers were wrapped in spirals around tubes. ${ }^{4}$ The model was meant to imitate at least the structure of the mainly load-bearing S2 layer in the wood cell. In the process, they were able to demonstrate several important analogies to wood, for instance, the strong dependence of mechanical properties on fiber orientation (MFA). Nonetheless, their model did not fully capture the wood cell in several respects because the other layers were not replicated and the model was many times larger than a wood cell. auch Bewegungen zu vollführen, zum Beispiel die Ausrichtung der Zweige zum Licht.

Als Auslöser für das Entstehen von Reaktionsholz können mehrere Faktoren genannt werden, zum Beispiel Licht und Gravitation, aber auch künstliche mechanische Stimuli. So wurde in einem Experiment in Schwerelosigkeit nachgewiesen, dass künstlich aufgebrachte Biegebelastung zu Reaktionsholzbildung in jungen Douglasie-Setzlingen führen. ${ }^{3}$ Das heißt, dass Pflanzen offensichtlich ein Sensorium für mechanische Belastung besitzen. In Versuchen mit Tannenästen konnten wir zeigen, dass künstliche Durchbiegung des Astes nach oben die Bildung von Druckholz mit hohem MFA auf dessen Oberseite hervorruft, obwohl sie sonst immer nur an der Unterseite beobachtet wird. Der Ast setzt der Biegung also Widerstand entgegen, und zwar nicht nur, wenn diese nach unten, sondern auch, wenn diese nach oben zum Licht hin erfolgt. Die genauen Mechanismen sind noch ungeklärt, könnten jedoch entscheidende Inspirationen für neue, bioinspirierte Faserverbund-Materialien mit optimierter Nanostruktur liefern.

Die Holzzelle direkt nachzubauen ist allerdings eine große Herausforderung und bisher aufgrund ihrer Komplexität und der geringen GröBe ihrer Komponenten noch nicht gelungen. Bisher finden sich nur einzelne Aspekte der Holzzellwand in neuen Verbundmaterialien verwirklicht. Ein vereinfachtes, makroskopisches Modell wurde zum Beispiel von Gordon und Jeronimidis hergestellt, indem sie Kohlefasern spiralförmig um Röhren wickelten. ${ }^{4}$ Dies sollte zumindest die Struktur der hauptsächlich lasttragenden S2-Schicht der Holzzelle imitieren. Sie konnten damit einige wichtige 


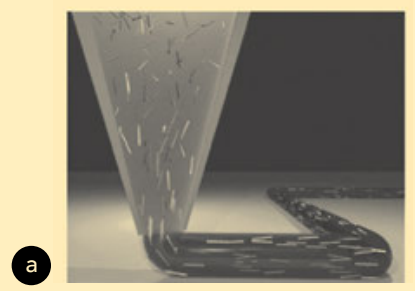

(b)
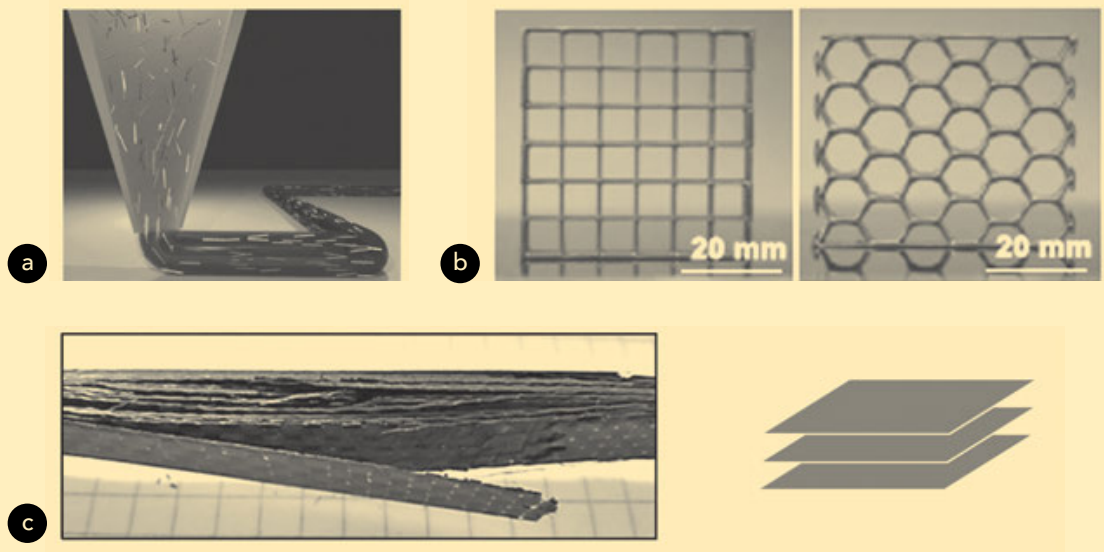

d

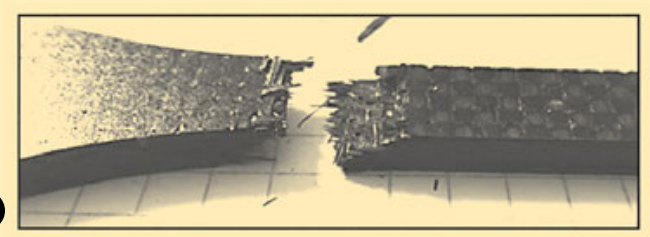

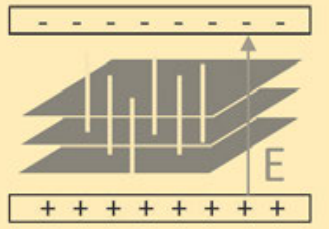

4 Figs. 3a-d | Abb. 3a-d:

Artificial composites with oriented nanofibers:

a) Orientation of short carbon fibers in liquid resin created by shearing in the print head, with permission from $\left[{ }^{10}\right]$. b) 3D-printed structures reinforced with nanofibers modeled after balsa wood, with permission from [6]. c) and d) Carbon-fiber composite made of woven fiber layers, once without (c) and once with (d) oriented carbon nanotubes as reinforcement.

Photos (C) H. Lichtenegger The nano reinforcement yields a much lower propensity to delamination.
Upscaling, however, always results in changes to the material properties. Nanocomposites in particular often exhibit substantially different behavior than macroscopic reinforcement elements due to the increasing interface area ratio between fibers and matrix, the smaller the reinforcing fibers are dimensioned. ${ }^{5}$

Thanks to steady improvements in technical capabilities, it is now possible to produce materials with oriented microfibers and nanofibers. The technique of 3D printing, or additive manufacturing, in particular, enables the manufacture of complex parts. For instance, structures resembling balsa wood were fabricated out of epoxy resin reinforced with short carbon fibers. ${ }^{6}$ During printing, fibers were oriented in the printing direction due to the shear forces exerted during the extrusion of the material from the print head (Fig. 3a). Unfortunately, this approach limits fiber orientation considerably. In usual printing techniques where the printing material is deposited by
Analogien zu Holz zeigen, wie beispielsweise die starke Abhängigkeit der mechanischen Eigenschaften von der Orientierung der Fasern (MFA). Dennoch wurde ihr Modell der Holzzelle in mehrerer Hinsicht nicht völlig gerecht, da die anderen Schichten nicht nachgebildet wurden und das Modell um ein Vielfaches größer war als eine Holzzelle. Eine Hochskalierung bleibt jedoch niemals ohne Veränderung der Materialeigenschaften. Insbesondere Nanoverbundwerkstoffe zeigen oft ein substanziell anderes Verhalten als makroskopische Verstärkungselemente, wegen der wesentlich größeren Grenzfläche zwischen Fasern und Matrix, je kleiner die verstärkenden Fasern dimensioniert werden. ${ }^{5}$

Mit den ständig verbesserten technischen Möglichkeiten können mittlerweile Materialien mit orientierten Mikro- und Nanofasern hergestellt werden. Insbesondere die Technik des 3D-Drucks (additive manufacturing) erlaubt die Herstellung komplexer Teile. So wurden beispielsweise balsaholzartige Strukturen auf Basis 
strand, cellular structures with a normal fiber orientation with respect to the longitudinal cell axis were able to be achieved, but a controlled tilt angle (MFA) was not.

Other concepts might be useful in this context. For instance, it was shown that it is possible to align nanofibers in external electrical and magnetic fields. If fibers in a liquid polymer matrix are brought into a strong electrical field, an effect called dielectrophoresis occurs. This means a dipole is created in the fibers that acts counter to the direction of the outer field. If the fiber is diagonal to the field, it experiences torque that aligns it in the direction of the field lines.

With this technique, we recently succeeded in manufacturing hierarchical composites modeled on the structure of the chitinous shell of crabs. ${ }^{7}$ In the process, layers of tissue made of micrometer-size carbon fibers were laid one on top of the other and saturated with a mixture of epoxy resin and carbon nanotubes. Then an electrical field was applied perpendicular to the carbon fiber layers. The carbon nanotubes aligned themselves with the field lines, thereby creating reinforcement between the fiber layers (Figs. $3 c$ and $3 d$ ). Polymerization of the epoxy resin fixed this orientation in place. The finished material exhibited greatly improved strength and above all, resistance to delamination compared to the control material without carbon nanotubes.

However, even this type of fiber orientation alone is not strong enough to build materials as complex as wood. Ultimately, we may be able to take a further step in this direction by combining the widest variety of methods. In the meantime, von Epoxidharz, verstärkt mit kurzen Kohlenstofffasern, hergestellt. ${ }^{6}$ Hier wurden während des Druckens Fasern aufgrund von Scherkräften beim Extrudieren des Materials aus dem Druckkopf in Druckrichtung orientiert (Abb. 3a). Leider bringt dies eine starke Einschränkung der Faserorientierung mit sich: Bei üblichen Drucktechniken, die strangweise Druckmaterial ablegen, konnten zelluläre Strukturen mit einer Faserorientierung normal zur Zell-Längsachse erzielt werden, aber kein kontrollierter Kippwinkel (MFA).

Hier könnten andere Konzepte hilfreich sein. Zum Beispiel wurde gezeigt, dass sich Nanofasern in externen elektrischen und magnetischen Feldern ausrichten lassen. Wenn Fasern in einer flüssigen Polymermatrix in ein starkes elektrisches Feld eingebracht werden, tritt der Effekt der Dielektrophorese ein. Das heißt, in den Fasern entsteht ein Dipol, der entgegen der Richtung des äußeren Feldes wirkt. Steht die Faser schräg zum Feld, so erfährt sie ein Drehmoment, welches sie in Richtung der Feldlinien ausrichtet.

Mit dieser Technik konnten wir kürzlich hierarchische Verbundwerkstoffe nach dem strukturellen Vorbild des Chitinpanzers von Krabben herstellen. ${ }^{7}$ Dabei wurden Gewebeschichten aus Mikrometer-großen Kohlenstofffasern aufeinandergelegt und mit einer Mischung aus Epoxidharz und Kohlenstoffnanoröhrchen getränkt. Danach wurde ein elektrisches Feld normal zu den Kohlenstofffaserlagen angelegt. Die Kohlenstoffnanoröhrchen richteten sich nach den Feldlinien aus und erzeugten so eine Verstärkung zwischen den Faserlagen (Abb. 3c und 3d). Die Ausrichtung wurde durch Polymerisation des Epoxidharzes fixiert. Das fertige Material wies eine deutlich verbesserte 
replicating wood as it exists in living trees remains unachievable, not least because it is an adaptive tissue capable of responding structurally to conditions in its environment - a capability that engineered materials will not be so quick to acquire. Nonetheless, we can more fully understand this model from nature even from the modest advances that have been made in fabricating and studying structures similar to those in wood.
Festigkeit und vor allem Resistenz gegen Delamination im Vergleich zum Vergleichsmaterial ohne Kohlenstoffnanoröhrchen auf.

Allerdings ist auch diese Art der Faserorientierung allein nicht mächtig genug, um Materialien mit der Komplexität von Holz zu bauen. Letztlich wird vielleicht eine Kombination von verschiedensten Methoden einen weiteren Schritt in diese Richtung bringen. Einstweilen bleibt Holz, wie wir es im lebenden Baum finden, als Material unerreicht, nicht zuletzt, da es sich um ein anpassungsfähiges Gewebe handelt, das strukturell auf seine Umweltbedingungen antworten kann - eine Fähigkeit, die technische Materialien so schnell nicht besitzen werden. Dennoch können wir schon aus den bescheidenen Fortschritten bei der Herstellung und Untersuchung von holzähnlichen Strukturen ein größeres Verständnis für das natürliche Vorbild gewinnen.

$1 \quad$ Reiterer, A., et al. (1999): "Experimental evidence for a mechanical function of the cellulose microfibril angle in wood cell walls," in: Philosophical Magazine A 79(9): 2173-2184.

2 Lichtenegger, H., et al. (1999): "Variation of Cellulose Microfibril Angles in Softwoods and Hardwoods. A Possible Strategy of Mechanical Optimization," in: Journal of Structural Biology 128(3): 257-269.

3 Kwon, M., et al. (2001): "Induced compression wood formation in Douglas fir (Pseudotsuga menziesii) in microgravity", in: Phytochemistry 57(6): 847-857.

4 Gordon, J. E., Jeronimidis, G. (1980): "Composites with high work of fracture", in: Philosophical Transactions of the Royal Society A - Mathematical Physical and Engineering Sciences 294(1411): 545-550.

5 Pulickel, M. A., Schadler, L. S., Braun, P. V. (eds.) (2004): Nanocomposite Science and Technology, Weinheim: Wiley-VCH.

6 Malek, S., et al. (2017): "Lightweight 3D cellular composites inspired by balsa", in: Bioinspir Biomim 12(2): 026014.

7 Singer, G., et al. (2019): "High performance functional composites by in-situ orientation of carbon nanofillers", in: Composite Structures 215: 178-184.

8 Rafsanjani, A., et al. (2014): Journal of The Royal Society Interface 11(95): 20140126.

9 Reiterer, A., et al. (2001): Journal of Material Science 36(19): 4681-4686.

10 Compton, B. G., Lewis, J. A. (2014): Adv Mater 26(34): 5930-5. 